\title{
Regional seesaw between the North Atlantic and Nordic Seas during the last glacial abrupt climate events
}

\author{
Mélanie Wary $^{1}$, Frédérique Eynaud ${ }^{1}$, Didier Swingedouw ${ }^{1}$, Valérie Masson-Delmotte ${ }^{2}$, Jens $_{\text {Matthiessen }}{ }^{3}$, \\ Catherine Kissel $^{2}$, Jena Zumaque ${ }^{1, a}$, Linda Rossignol ${ }^{1}$, and Jean Jouzel ${ }^{2}$ \\ ${ }^{1}$ UMR 5805, EPOC (Environnements et Paléoenvironnements Océaniques et Continentaux), \\ CNRS-EPHE-Université de Bordeaux, 33615 Pessac, France \\ ${ }^{2}$ UMR8212, LSCE (Laboratoire des Sciences du Climat et de l'Environnement)/IPSL (Institut Pierre Simon Laplace), \\ CEA/CNRS-INSU/UVSQ, 91191 Gif-sur-Yvette CEDEX, France \\ ${ }^{3}$ AWI (Alfred Wegener Institute), Helmholtz Centre for Polar and Marine Research, 27568 Bremerhaven, Germany \\ anow at: GEOTOP, UQAM, Montréal, Québec H3C 3P8, Canada
}

Correspondence to: Mélanie Wary (melanie.wary@u-bordeaux.fr)

Received: 7 February 2017 - Discussion started: 13 February 2017

Revised: 19 May 2017 - Accepted: 25 May 2017 - Published: 30 June 2017

\begin{abstract}
Dansgaard-Oeschger oscillations constitute one of the most enigmatic features of the last glacial cycle. Their cold atmospheric phases have been commonly associated with cold sea-surface temperatures and expansion of sea ice in the North Atlantic and adjacent seas. Here, based on dinocyst analyses from the 48-30 ka interval of four sediment cores from the northern Northeast Atlantic and southern Norwegian Sea, we provide direct and quantitative evidence of a regional paradoxical seesaw pattern: cold Greenland and North Atlantic phases coincide with warmer sea-surface conditions and shorter seasonal sea-ice cover durations in the Norwegian Sea as compared to warm phases. Combined with additional palaeorecords and multi-model hosing simulations, our results suggest that during cold Greenland phases, reduced Atlantic meridional overturning circulation and cold North Atlantic sea-surface conditions were accompanied by the subsurface propagation of warm Atlantic waters that reemerged in the Nordic Seas and provided moisture towards Greenland summit.
\end{abstract}

\section{Introduction}

The last glacial cycle has been punctuated by abrupt climatic variations strongly imprinted in Greenland ice core records where they translate into millennial oscillations between cold (Greenland stadial, GS) and warm (Greenland interstadial, GI) atmospheric phases (e.g., North Greenland
Ice Core Project members, 2004). They are tightly linked to pan-North Atlantic ice-sheet dynamic that manifests itself by cyclic iceberg releases concomitant with GS (Bond and Lotti, 1995). These variations are thought to be linked to changes in the North Atlantic meridional overturning circulation, potentially in response to iceberg-derived freshwater injections in the North Atlantic (Kageyama et al., 2010). A few palaeoclimatic studies (Dokken and Jansen, 1999; Rasmussen and Thomsen, 2004; Dokken et al., 2013) and sensitivity tests performed with atmospheric models ( $\mathrm{Li}$ et al., 2010) have also suggested that the expansion of sea ice in the Nordic Seas during GS could be a key amplifier, explaining the large $5-16^{\circ} \mathrm{C}$ magnitude of Greenland cooling (Kindler et al., 2014). However, cold sea-surface temperatures (SSTs) and expansion of sea ice during GS were mainly inferred from indirect marine proxy records, such as significant increases in ice-rafted debris concentration or variations in the relative abundance and oxygen isotopic content of the polar planktonic foraminifera Neogloboquadrina pachyderma sinistral coiling (NPS) (Bond and Lotti, 1995; Dokken and Jansen, 1999; Rasmussen and Thomsen, 2004; Dokken et al., 2013) whose preferential depth habitat lies from a few tens of metres to around $250 \mathrm{~m}$ water depth in the Nordic Seas (e.g. Simstich et al., 2003). The occurrence of a pycnocline separating this cold and sea-ice-covered surface layer from warmer Atlantic subsurface waters have also been reported during GS on the basis of these and other planktonic 
foraminifera data supported by benthic foraminifera ones however, sometimes interpreted in different ways (e.g. Rasmussen and Thomsen, 2004; Dokken et al., 2013). In parallel, the few direct but qualitative sea-ice reconstructions based on lipid biomarker analyses (Müller and Stein, 2014; Hoff et al., 2016) yielded contrasting interpretations. Here, we provide direct and quantitative reconstructions of variations of seasurface conditions from a compilation of three Norwegian Sea cores and one northern Northeast Atlantic core strategically positioned across the Faeroe-Iceland Ridge to track rapid hydrographic changes (Dokken and Jansen, 1999; Eynaud et al., 2002; Rasmussen and Thomsen, 2004; Dokken et al., 2013) (Fig. 1a and Table S1 in the Supplement). We focus on Marine Isotopic Stage 3 (MIS 3, 30-48 ka cal BP), when millennial variability is strongly imprinted, and accurate chronologies can be established (Austin and Hibbert, 2012). In parallel to these reconstructions, we also use subsurface palaeohydrographical data, freshwater hosing simulations and ice core-derived atmospheric data to assess the ocean-cryosphere-atmosphere interactions associated with this abrupt climate variability.

\section{Methods}

\subsection{Stratigraphy}

For the four studied cores, new age models have been established on the basis of radiocarbon AMS ${ }^{14} \mathrm{C}$ dates coupled to additional tie-points obtained by correlating their magnetic susceptibility records with the NGRIP $\delta^{18} \mathrm{O}$ signal (North Greenland Ice Core Project members, 2004) (GICC05 timescale; Svensson et al., 2008). This approach is in line with the current consensus that, in this region, increases (or decreases) in magnetite content (here, magnetic susceptibility reflecting deep sea currents strength; Kissel et al., 1999) are synchronous with the onset of GI (or onset of GS; Kissel et al., 1999; Austin and Hibbert, 2012). Cores MD95-2009, MD95-2010 and MD99-2281 also benefit from additional climate-independent age control points supporting these new age models. A more detailed discussion on the age models can be found in the Supporting Information (Sect. S1, Fig. S1, and Table S2 in the Supplement; Martinson et al., 1987; Manthé, 1998; Laj et al., 2004; Rasmussen et al., 2006; Zumaque et al., 2012; Caulle et al., 2013; Reimer et al., 2013; Wolff et al., 2010; Wary et al., 2016).

\subsection{Sea-surface conditions}

Sea-surface conditions are estimated from a transfer function sensu lato applied to dinocyst - or dinoflagellate cyst assemblages using the modern analogue technique (de Vernal and Rochon, 2011) (see Sect. S2 for further details on the methodology; Rochon et al., 1999; Head et al., 2001; Telford and Birks, 2005, 2009, 2011; Telford, 2006; Guiot and de Vernal, 2007, 2011a, b; Birks et al., 2010; Radi et al., 2013; de Vernal et al., 2013a, b; Trachsel and Telford, 2016). As dinoflagellates are mostly restricted to the uppermost $50 \mathrm{~m}$ water depth (Sarjeant, 1974), they are assumed to directly reflect sea-surface conditions (see Sect. S6 for further details). We provide here new sea-surface reconstructions for cores MD95-2009, MD95-2010 and MD99-2281 based on previously published dinocyst counts (Eynaud et al., 2002; Eynaud, 2003a, b; Zumaque et al., 2011) and extend the previously published reconstructions for core MD99-2285 (Wary et al., 2016; see also Wary et al., 2017 for the complete raw dinocyst counts of core MD99-2285). Our statistical approach provides direct and quantitative reconstructions for mean summer and mean winter SST (with, in the present case, root mean square errors of prediction - RMSEP - of 1.5 and $1.05^{\circ} \mathrm{C}$, respectively), mean summer and mean winter sea-surface salinities (SSS; respective RMSEP of 2.4 and $2.3 \mathrm{psu}$ ), and mean annual sea-ice cover (SIC) duration (RMSEP of 1.2 months year $^{-1}$ ).

\subsection{Model simulations}

We compare our reconstructions with freshwater hosing experiments conducted using five state-of-the-art climate models (Swingedouw et al., 2013). Four of them are coupled ocean-atmosphere models (HadCM3, IPSLCM5A, MPIESM, EC-Earth) and one is an ocean-only model (ORCA05) (see Supplement Sect. S3 and Table S3; Gordon et al., 2000; Biastoch et al., 2008; Sterl et al., 2012; Dufresne et al., 2013; Jungclaus et al., 2013). One of the models (BCM2) reported in the original study (Swingedouw et al., 2013) has been considered as an outlier and consequently excluded from the present study (see Supplement Sect. S3 for further details). Two types of simulations are considered: (i) the transient control simulations, corresponding to historical simulations without any additional freshwater input, and (ii) the hosing simulations, corresponding to historical simulations with an additional freshwater input of $0.1 \mathrm{~Sv}$ released on all the coastal grid points around Greenland with a homogeneous rate during 40 years (over the historical era 1965-2004, except for HadCM3 and MPI-ESM, for which the experiments were performed over the periods 1960-1999 and 1880-1919, respectively). Several variables have been analysed: oceanic temperatures (Fig. 1b and d), surface ( $2 \mathrm{~m}$ ) atmospheric temperatures (Fig. 1c), and barotropic stream function (Fig. S6). Anomalies were calculated as the differences between hosing and control experiments averaged over the 4th decade.

Earlier studies have shown that the response (spatial pattern, amplitudes, etc.) to freshwater discharges in the North Atlantic depends on several factors including climatic boundary conditions (Swingedouw et al., 2009; Kageyama et al., 2010). Differences of sensitivity to freshwater perturbations in Last Glacial Maximum (LGM) conditions compared to interglacial conditions have been mainly ascribed to differences in ice-sheet and sea-ice configurations. As millennial climatic variability is strongest during MIS 3, it would have 

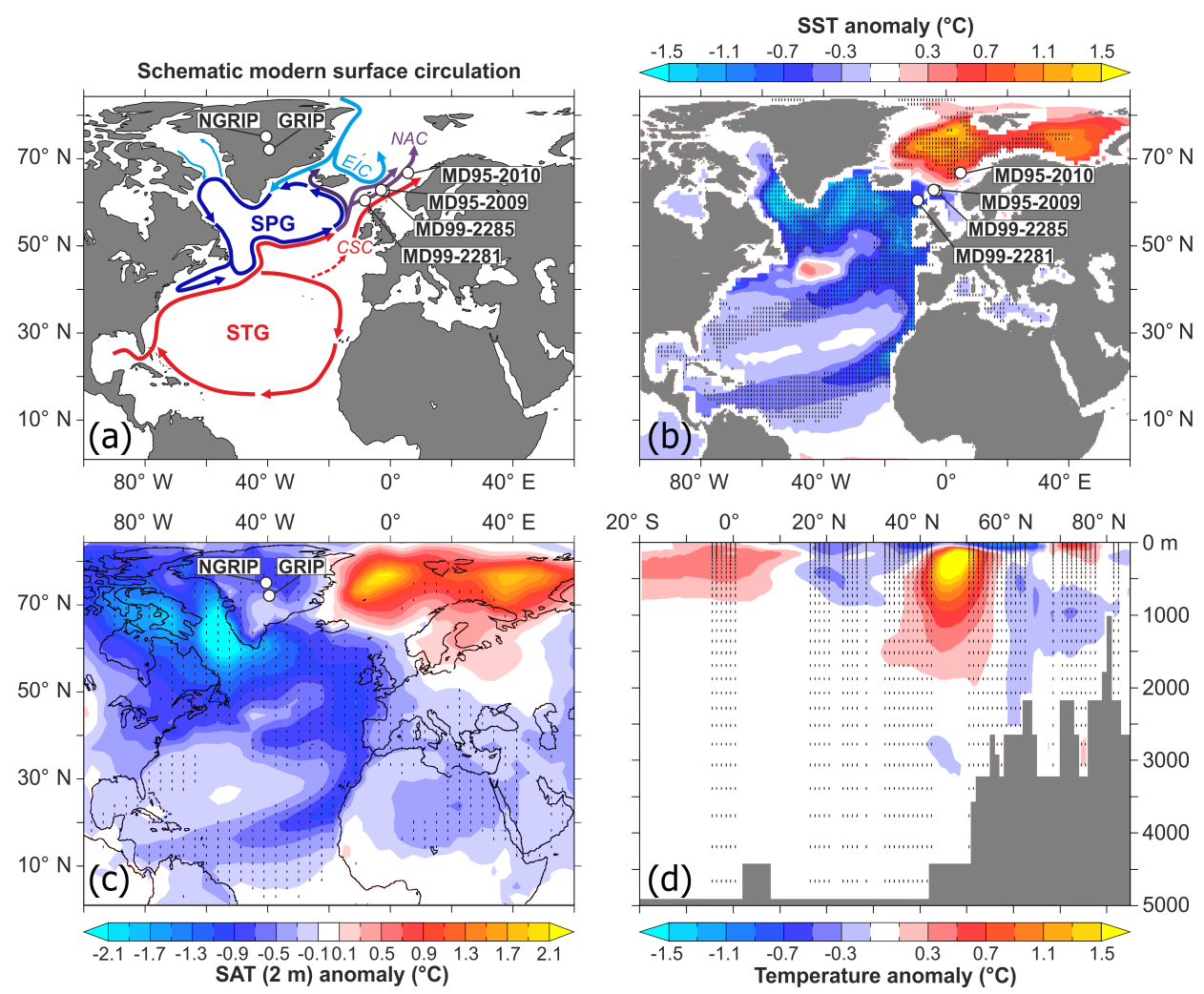

Figure 1. Hydrographical context and five-member ensemble mean of temperature anomalies between hosing and control experiments. (a) Schematic surface current pattern (STG, subtropical gyre; SPG, subpolar gyre; CSC, Continental Slope Current; NAC, North Atlantic Current; EIC, East Icelandic Current). (b, c) Five-member ensemble mean of SST (b) and surface atmospheric temperature (c) anomalies $\left({ }^{\circ} \mathrm{C}\right)$. (d) Latitude-depth section of the five-member ensemble mean of oceanic temperature anomalies $\left({ }^{\circ} \mathrm{C}\right.$, zonal average over the Atlantic Ocean). Also shown are the locations of the studied marine cores (MD95-2010, MD95-2009, MD99-2285, MD99-2281) and Greenland ice cores (NGRIP, GRIP). Black dashes indicate grid points where all models converge on the anomaly sign.

been optimal to compare our MIS 3 data to simulations run under MIS 3 conditions rather than pre-industrial ones. However, MIS 3 boundary conditions, and especially cryospheric conditions, are poorly constrained and set at an intermediate level between LGM and present-day boundary conditions (Van Meerbeeck et al., 2009). Nevertheless, it will be worth comparing our reconstructions with MIS 3 simulations conducted using the same state-of-the-art multi-model approach with standardized volume and duration of freshwater flux as soon as such simulations will be available.

\subsection{Complementary data}

To complement our view of the system, we also compare our sea-surface hydrographical reconstructions with (i) the relative abundance of the mesopelagic polar planktonic foraminifera NPS obtained in the same cores (Eynaud et al., 2002; Zumaque et al., 2012; Wary, 2015) and considered as tracer of cold subsurface conditions (see Supplement Sects. S5 and S6 for further details; Carstens and Wefer, 1992; Bauch et al., 1997; Carstens et al., 1997; Hillaire-Marcel and Bilodeau, 2000; Volkmann and Men- sch, 2001; Simstich et al., 2003; Hillaire-Marcel et al., 2004; Kretschmer et al., 2016), and (ii) Greenland ice core deuterium excess data as indicator of Greenland moisture origin (Masson-Delmotte et al., 2005).

\section{Results and discussion}

Our sea-surface reconstructions reveal contrasted responses of the southeastern Nordic Seas compared to the northeastern Atlantic (Fig. 2, Tables 1, 2 and 3). The Atlantic core MD99-2281 exhibits lower SST during GS compared to GI, and a very short SIC duration throughout MIS3. Paradoxically, the three Norwegian Sea cores record higher SST and shorter SIC durations during the cold North Atlantic GS, and lower SST and longer SIC durations during the warm North Atlantic GI. This atypical pattern is robustly observed in all the three Norwegian Sea sequences, despite distinct physiographical contexts, and strongly expressed in the $63^{\circ} \mathrm{N}$ cores At this latitude, SST is systematically anti-correlated against Greenland and North Atlantic temperatures (Table 3), and shows large positive mean annual anomalies in GS compared to $\mathrm{GI}$ from $+1.7^{\circ} \mathrm{C}$ (MD95-2009) to $+3.7^{\circ} \mathrm{C}$ (MD99-2285) 
Table 1. SST anomalies.

\begin{tabular}{|c|c|c|c|c|c|c|c|c|c|}
\hline \multirow[t]{2}{*}{ Core } & \multicolumn{2}{|c|}{$\begin{array}{l}\text { Number of } \\
\text { samples }\end{array}$} & \multicolumn{3}{|c|}{$\begin{array}{l}\text { GS SST } \\
\left({ }^{\circ} \mathrm{C}\right)\end{array}$} & \multicolumn{3}{|c|}{$\begin{array}{l}\text { GI SST } \\
\left({ }^{\circ} \mathrm{C}\right)\end{array}$} & \multirow[t]{2}{*}{$\begin{array}{r}\text { Mean annual SST } \\
\text { anomalies (GS-GI; }{ }^{\circ} \mathrm{C} \text { ) }\end{array}$} \\
\hline & GS & GI & $\begin{array}{r}\text { mean } \\
\text { winter }\end{array}$ & $\begin{array}{r}\text { mean } \\
\text { summer }\end{array}$ & $\begin{array}{r}\text { mean } \\
\text { annual }\end{array}$ & $\begin{array}{l}\text { mean } \\
\text { winter }\end{array}$ & $\begin{array}{r}\text { mean } \\
\text { summer }\end{array}$ & $\begin{array}{r}\text { mean } \\
\text { annual }\end{array}$ & \\
\hline MD99-2281 & 23 & 39 & 0.9 & 14.6 & 7.8 & 1.5 & 14.4 & 8.0 & -0.2 \\
\hline MD99-2285 & 26 & 22 & 0.9 & 10.9 & 5.9 & -0.6 & 4.9 & 2.2 & 3.7 \\
\hline MD95-2009 & 12 & 17 & 0.3 & 11.0 & 5.6 & -0.4 & 8.3 & 4.0 & 1.7 \\
\hline MD95-2010 & 6 & 9 & 0.6 & 13.4 & 7.0 & 0.2 & 12.4 & 6.1 & 0.9 \\
\hline
\end{tabular}

Table 2. SIC duration anomalies.

\begin{tabular}{|c|c|c|c|c|c|}
\hline \multirow[t]{2}{*}{ Core } & \multicolumn{2}{|c|}{$\begin{array}{l}\text { Number of } \\
\text { samples }\end{array}$} & \multirow{2}{*}{$\begin{array}{r}\text { GS SIC } \\
\left.\text { (months yr }{ }^{-1}\right) \\
\text { mean annual }\end{array}$} & \multirow{2}{*}{$\begin{array}{r}\text { GI SIC } \\
\text { (months } \mathrm{yr}^{-1} \text { ) } \\
\text { mean annual }\end{array}$} & \multirow[t]{2}{*}{$\begin{array}{l}\text { Mean annual SIC anomalies } \\
\qquad\left(\mathrm{GS}-\mathrm{GI} \text {; months } \mathrm{yr}^{-1}\right)\end{array}$} \\
\hline & GS & GIS & & & \\
\hline MD99-2281 & 23 & 39 & 0.9 & 0.6 & 0.3 \\
\hline MD99-2285 & 26 & 22 & 3.2 & 6.2 & -3.0 \\
\hline MD95-2009 & 12 & 17 & 3.4 & 4.4 & -1.0 \\
\hline MD95-2010 & 6 & 9 & 2.0 & 2.7 & -0.7 \\
\hline
\end{tabular}

(see Supplement Sect. S4 for details on the calculation of anomalies; Wolff et al., 2010). Despite lower resolution and sensitivity, SST records from MD95-2010 also denote a positive GS mean annual SST anomaly $\left(+0.9^{\circ} \mathrm{C}\right)$, and cooling during GI is further supported by increases in the relative percentage of the polar, sea-ice-linked dinocyst Islandinium minutum (\% I.MIN; Supplement Sect. S2 and Figs. S2 and S3; Rochon et al., 1999; Radi et al., 2013; Heikkilä et al., 2014, 2016). Previous palaeoclimatic studies (e.g. de Vernal et al., 2006) evidenced a similar regional SST seesaw pattern during the LGM, with also sometimes warmer than modern SST in the Nordic Seas, suggesting that such a situation might represent a regular feature for glacial periods.

In order to investigate the mechanisms involved in this regional seesaw, we analyse the multi-model freshwater hosing simulations from Swingedouw et al. (2013). The fivemember ensemble mean of the differences between hosing and control experiments shows large surface warming in the Nordic Seas while the rest of the North Atlantic surface is strongly cooled in response to freshwater input around Greenland (Fig. 1b). This regional seesaw pattern is robust in the five individual simulations and consistent with concomitant atmospheric cooling above Greenland (Fig. 1c). While the simulated multi-model mean surface warming is weaker than the palaeodata-derived one, some individual simulations produce SST increase of up to $4.2^{\circ} \mathrm{C}$ in the Nordic Seas (Swingedouw et al., 2013). The multi-model simulations also depict significant sea-ice retreat in the Nordic Seas and seaice expansion in the Atlantic sector and Labrador Sea (see Fig. 10 in Swingedouw et al., 2013).

An earlier modelling study (Kleinen et al., 2009) also depicted surface warming of the Nordic Seas in response to a freshwater perturbation, independently from the location of the freshwater input. It was attributed to the subsurface propagation of warm Atlantic water masses beneath the cold North Atlantic meltwater lid (resulting from the freshwater input) up to the Norwegian Sea, where they re-emerge and mix with ambient waters. Our model simulations indeed show a positive subsurface heat anomaly south of the Greenland-Scotland sill, located below the North Atlantic freshwater lid (Fig. 1d). This freshwater lid has two important consequences: (i) it prevents oceanic vertical mixing which normally transfers winter surface cooling (due to atmospheric heat fluxes) into subsurface, and (ii) it induces hydrographical reorganizations where subpolar gyre transport decreases but water-mass transport from the subtropics into the Nordic Seas increases, especially along the eastern North Atlantic boundary (see Hátún et al., 2005; Kleinen et al., 2009, and Fig. S6).

Although simulated here under present-day background conditions, this physical process may have occurred during stadials in response to meltwater release and provides an explanation for the regional seesaw SST and SIC pattern. A few earlier palaeoclimate studies have indeed suggested enhanced advection of warm Atlantic waters through the Continental Slope Current (flowing poleward along the eastern North Atlantic boundary) during stadial intervals (Peck et al., 2008, based on a core from the Porcupine Seabight) in response to a meltwater release detected at GI-GS transitions (see Wary et al., 2016). Compared to the modern climate system, the potentially reduced northward baroclinic volume transport of Atlantic waters associated with a weaker stadial deep-convection in the Nordic Seas could have been counteracted by (i) an increased northward barotropic transport (with 
Table 3. Correlation coefficients over the 48-30 ka cal BP interval between Greenland temperatures (NGRIP $\delta^{18} \mathrm{O}$; North Greenland Ice Core Project members, 2004; Svensson et al., 2008), North Atlantic (MD99-2281) and Norwegian Sea (MD99-2285, MD95-2009, MD95-2010) winter SST.

\begin{tabular}{rrrrrr}
\hline & \multicolumn{4}{c}{ Winter SST } \\
\cline { 3 - 6 } & MD99-2281 & MD99-2285 & MD95-2009 & MD95-2010 \\
\hline \multirow{2}{*}{ NGRIP $\delta^{18}$ O } & 0.24 & -0.45 & -0.42 & -0.10 \\
& MD99-2281 & & -0.31 & -0.31 & 0.18 \\
Winter SST & MD99-2285 & & 0.59 & -0.08 \\
& MD95-2009 & & & -0.11 \\
\hline
\end{tabular}

compensation through a larger export at the Denmark Strait for instance), (ii) a larger heat transport due to higher temperature anomalies in the source area, and/or (iii) a greater impact of this northward heat transport on Nordic Seas SST thanks to a larger insolation forcing during MIS3 (Berger and Loutre, 1991).

We now consider subsurface information from our records to complement this mechanism (Fig. 2). Consistent with earlier palaeoceanographic studies within the Nordic Seas (Rasmussen and Thomsen, 2004) and the North Atlantic (Bond and Lotti, 1995; Rasmussen and Thomsen, 2004; Eynaud et al., 2009; Jonkers et al., 2010), all our cores reveal the occurrence of colder planktonic foraminiferal assemblages during GS, characterized here by nearly $100 \%$ of the mesopelagic taxon NPS. This testifies to the presence of cold polar waters (Eynaud et al., 2009) below a few tens of metres of water depth.

Altogether, this implies the following oceanographic situation during GS: a reduced Atlantic meridional overturning circulation due to large meltwater fluxes (related to and/or sustained by iceberg releases), a southward migration of polar waters, a colder and fresher North Atlantic surface, and a small northward subsurface flow of warm Atlantic waters, propagating below the North Atlantic meltwater lid (and below NPS depth habitat) before re-emerging at the surface of the Norwegian Sea, above colder polar waters (Fig. 3).

During GS, the upper part of the water column (topmost tens of metres) consists of a layer characterized by fairly high temperatures, notably during summer (Table 1), due to increased heat transport associated with Atlantic waters without heat loss. Dinocyst-derived sea-surface salinities (Table S4) depict relatively low values, around 31.7 psu over the entire study area, which are likely unfavourable to the development of subpolar surface to mid-surface dweller planktonic foraminifera despite fairly high SST (see Sect. S5 for further details; Tolderlund and Bé, 1971). These low salinities are probably due to (i) surface meltwater produced by iceberg releases within the Nordic Seas, evidenced by icerafted peaks during GS (Elliot et al., 2001), and (ii) the seasonal melting of (reduced) sea ice and surrounding glaciers. At the base of this warm and low saline layer, the nearly $100 \%$ NPS indicates colder (at least during summer) and probably slightly saltier waters than in the upper layer (Tolderlund and Bé, 1971).

Using indirect proxies, earlier studies (Rasmussen and Thomsen, 2004; Dokken et al., 2013) had suggested the existence of a strong pycnocline separating cold and fresh surface waters from warm and salty Atlantic subsurface waters during GS. Our direct reconstructions depict a more complex temperature-depth pattern but also imply a pycnocline. This stratification of the upper water column results in strong seasurface seasonality contrasts as depicted by dinocysts during GS (Supplement Sect. S2 and Fig. S4; Locarnini et al., 2010). They are explained by the relatively low thermal inertia of the low salinity surface waters, and the limited winter sea-ice extent. Sea-ice cover duration is less than 3.5 months year $^{-1}$ at the study sites. Reduced sea-ice formation during GS compared to GI possibly relates to the heat transport by the Atlantic waters, in an orbital context during MIS3 with high summer insolation at $65^{\circ} \mathrm{N}$ (Berger and Loutre, 1991).

During GI (Fig. 3), coherent sea-surface and subsurface patterns are reconstructed in the four sediment cores, reflecting the disappearance or deepening of the pycnocline. The Norwegian Sea is then characterized by lower SST, reduced seasonal SST contrasts, and $100 \%$ NPS, reflecting a thick homogenous mixed layer consisting of cold polar waters, as well as longer sea-ice cover durations. In the Atlantic sector, core MD99-2281 exhibits less than 50\% NPS, higher SST and reduced seasonal SST contrasts, indicating a thick and weakly stratified mixed layer where polar waters and Atlantic waters mix.

Our new paradigm is thus consistent with a scenario of subsurface and intermediate-depth warming during GS in the North Atlantic (Jonkers et al., 2010; Marcott et al., 2011) and in the Nordic Seas (Rasmussen and Thomsen, 2004; Marcott et al., 2011; Dokken et al., 2013; Ezat et al., 2014), where reconstructed subsurface and intermediate-depth temperatures are considerably lower than our reconstructed summer SST. Such subsurface warming might be due to the insulation by the North Atlantic meltwater lid and downward diffusion of heat in the Nordic Seas.

It is not incompatible with the "brine hypothesis" (Dokken and Jansen, 1999; Dokken et al., 2013) formulated to explain the isotopically light $\delta^{18} \mathrm{O}$ values measured on NPS during 

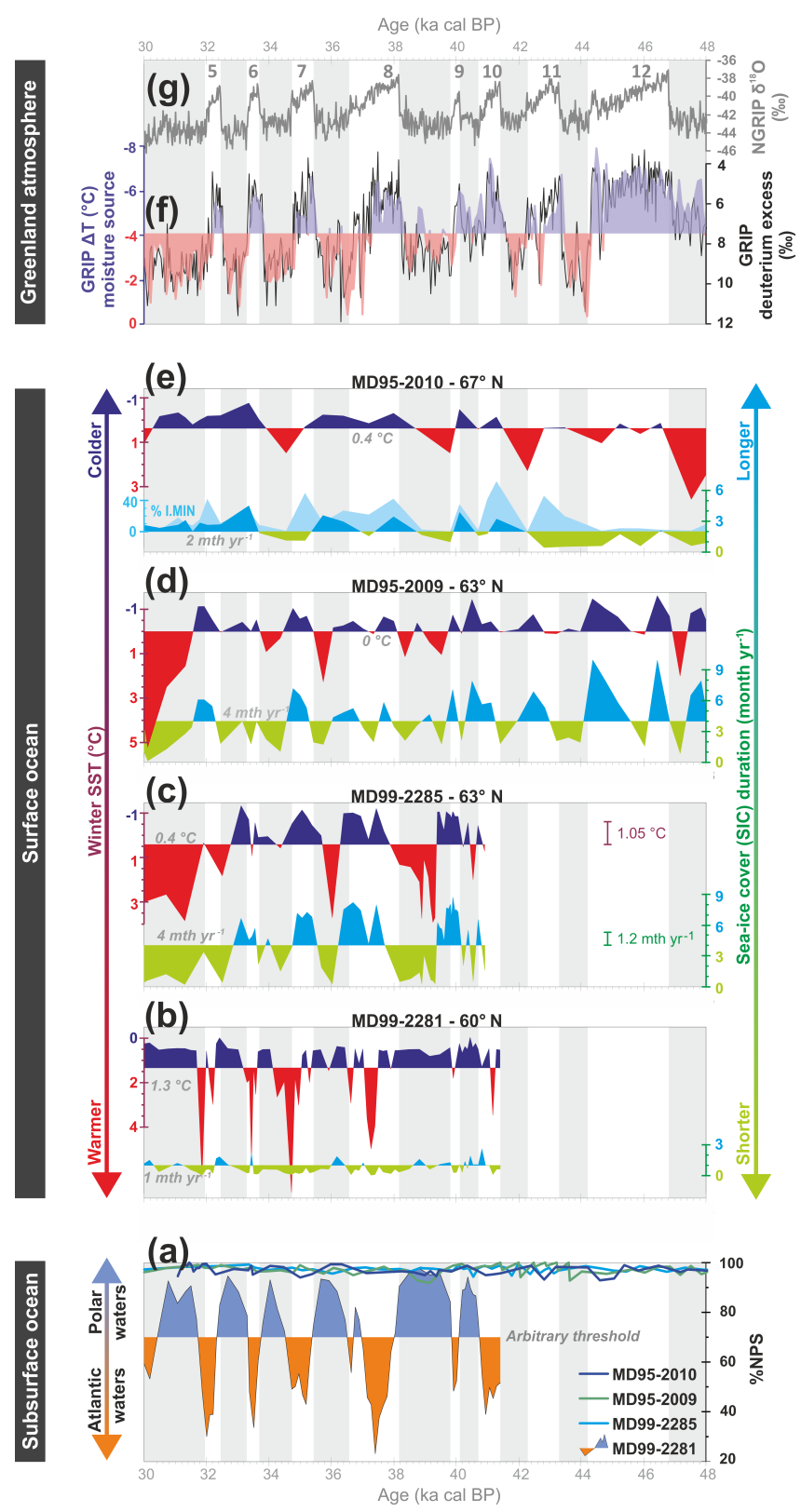

Figure 2. Proxy records. (a) \%NPS (shading in MD99-2281 at an arbitrary threshold to better illustrate changes). (b-e) SST and SIC records, shaded relatively to the mean value (indicated in grey) of the parameter over the studied period. Error bars are shown in panel (c). \%I.MIN of MD95-2010 is also shown. (f) GRIP deuterium excess record and associated reconstructed source temperature anomaly (compared to modern value) of the evaporative source region for Greenland precipitation, assuming no change in humidity (Masson-Delmotte et al., 2005) (shaded relatively to its mean value over the studied period). (g) NGRIP $\delta^{18} \mathrm{O}$ (GICC05 age scale; North Greenland Ice Core Project members, 2004; Svensson et al., 2008). Grey bands highlight stadial periods.
GS within cores from the southern Nordic Seas, including core MD95-2010 (Dokken and Jansen, 1999), if we take into account changes of upper stratification during GS/GI and seasonality of NPS production period in the Nordic Seas (Simstich et al., 2003). During GS (strong stratification), NPS $\delta^{18} \mathrm{O}$ may reflect reduced winter shelf brine production - stored within the subsurface layer inhabited by NPS - rather than the seasonal melting, trapped in surface. During GI (weak stratification), NPS $\delta^{18} \mathrm{O}$ may then only reflect the large summer melting of sea ice which produces isotopically heavier waters (Hillaire-Marcel and de Vernal, 2008). It is worth noting that the isotopically light brine extrusion is produced during winter, when NPS is nearly absent, and is expected to form bottom waters through convective processes without stagnating at the base of the mixed layer.

The reconstructed SST pattern has implications for atmospheric circulation, moisture sources, and interpretation of Greenland ice core water stable isotope records, especially deuterium excess data (Masson-Delmotte et al., 2005) (Fig. 2). Recent monitoring data have revealed that (i) deuterium excess is low for subtropical Atlantic vapour and high for vapour formed at the Arctic sea-ice margin, where high kinetic fractionation occurs due to low relative humidity, and (ii) this vapour deuterium excess is preserved during transportation towards Greenland (Jouzel et al., 2013; Bonne et al., 2015). Higher deuterium excess recorded during GS (Masson-Delmotte et al., 2005) may reflect enhanced contribution of moisture from the Nordic Seas towards Greenland (as also previously suggested for Heinrich stadial 4 interval; Wary et al., 2016), when the Norwegian Sea appears relatively warm and surrounded by sea-ice-covered areas (providing low humidity air masses), while the North Atlantic surface is cold and marked by large sea-ice expansion (Hillaire-Marcel and de Vernal, 2008).

\section{Conclusions}

Our description of regional patterns and oceanographic processes occurring during MIS3 within the North Atlantic and the Nordic Seas is thus consistent with all existing palaeoclimate information and with climate simulations in response to freshwater forcing. During GS, we evidence large surface warming in the Norwegian Sea, in response to high-latitude freshwater release and subsequent regional ocean reorganizations. Such warming might have enhanced iceberg releases from the bordering ice sheets, and might have therefore constituted a positive feedback for freshwater release. The origin of the freshwater-forcing input is still enigmatic, and may be related to, or precede (Barker et al., 2015; Wary et al., 2016), massive iceberg calving episodes. Our findings thus highlight an original case study for climate-ice-sheet interactions, and calls for additional numerical simulations focused on oceansea-ice-atmosphere interactions during MIS 3 millennial climatic events. As a first step, evidencing such a warming of 
(a)
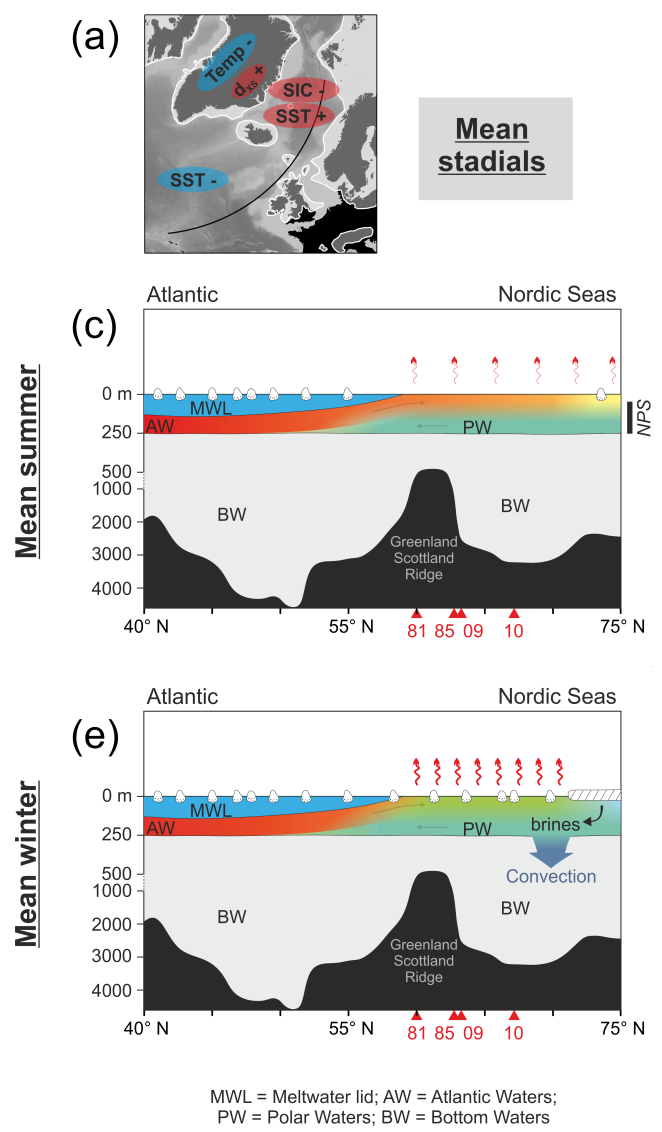

(b)

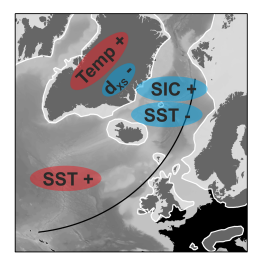

Mean

interstadials
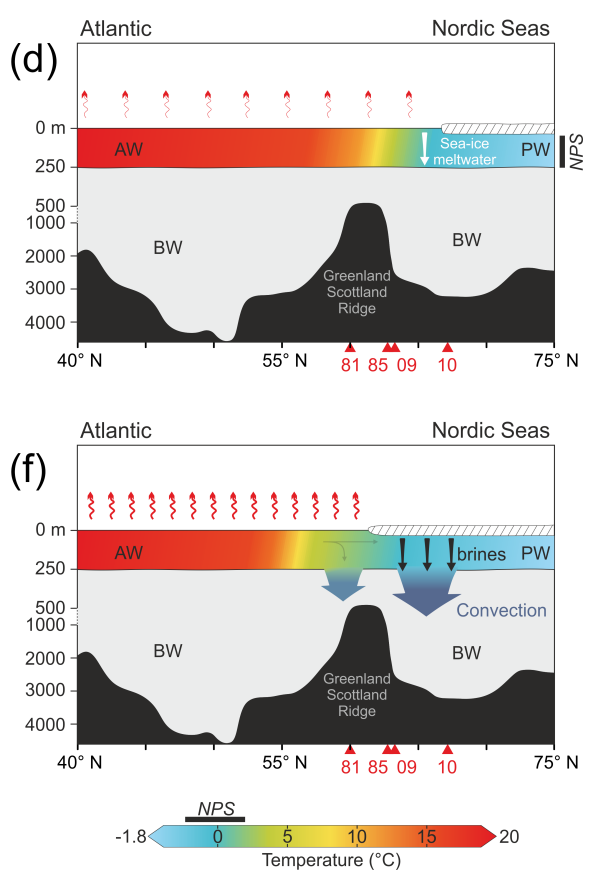

Figure 3. Conceptual hydrographical scheme. The diagrams depict the mean conditions in the sub-boreal Atlantic during stadials (left, a, c, e)/interstadials (right, b, d, f), and summer (middle panels, c, d)/winter (lower panels, e, f). Section location is indicated on the top maps. Bathymetry is from GEBCO (www.gebco.net), and has been simplified for sections. Ice-sheet extent on maps corresponds to the Last Glacial Maximum extension (Ehlers and Gibbard, 2007). Colours indicate temperature range, as indicated by the bottom scale. Potential depth range (Simstich et al., 2003) and optimal temperature range (Tolderlund and Bé, 1971) of NPS habitat, whose main production period occurs in summer in the Nordic Seas (Simstich et al., 2003), are also indicated.

the Nordic Seas in response to a standardized freshwater release in the subpolar gyre in an ensemble of state-of-the-art climate models under MIS3 conditions will be a prerequisite.

Data availability. Data used in this study are available upon request to Mélanie Wary (melanie.wary@u-bordeaux.fr) and Frédérique Eynaud (frederique.eynaud@u-bordeaux.fr).

\section{The Supplement related to this article is available online at https://doi.org/10.5194/cp-13-729-2017-supplement.}

Competing interests. The authors declare that they have no conflict of interest.
Acknowledgements. We thank Marie-Hélène Castéra for technical assistance, Didier Roche, Florian Ziemen, Uwe Mikolajewicz, Maria Fernanda Sánchez Goñi, Masa Kageyama, Mary Elliot, Aurélie Penaud, and Fabienne Marret-Davies for discussions, and Sandrine Manthé for MD95-2009 and MD95-2010 planktonic foraminiferal counts. Analyses performed on MD99-2285 were supported by the French INSU (Institut National des Sciences de l'Univers) programme LEFE (Les enveloppes fluides et l'environnement) within the frame of the EVE (Evolution et variabilité du climat à l'échelle globale) 2009-2011 project "RISCC: Rôle des Ice-Shelves dans le Changement Climatique" and of the IMAGO (Interactions multiples dans l'atmosphère, la glace et l'océan) 2013 project "ICE-BIO-RAM: Impact des Changements Environnementaux sur la BIOdiversité marine lors des Réchauffements Abrupts du cliMat", this latter being also supported by the INTERRVIE (Interactions Terre/Vie) - TS (Terre solide) INSU programme. We also acknowledge financial supports and facilities of the ARTEMIS 14C AMS French INSU project. The research leading to these results also benefited from fundings from the European Union's Seventh Framework programme (FP7/2007-2013) under grant agreement no 243908, "Past4Future. 
Climate change - Learning from the past climate" and from Agence Nationale de la Recherche (ANR) "Greenland" project (grant ANR-10-CEPL-0008).

Edited by: David Thornalley

Reviewed by: three anonymous referees

\section{References}

Austin, W. E. N. and Hibbert, F. D.: Tracing time in the ocean: A brief review of chronological constraints (60-8 kyr) on North Atlantic marine event-based stratigraphies, Quaternary Sci. Rev., 36, 28-37, https://doi.org/10.1016/j.quascirev.2012.01.015, 2012.

Barker, S., Chen, J., Gong, X., Jonkers, L., Knorr, G., and Thornalley, D.: Icebergs not the trigger for North Atlantic cold events, Nature, 520, 333-336, https://doi.org/10.1038/nature14330, 2015.

Bauch, D., Carstens, J., and Wefer, G.: Oxygen isotope composition of living Neogloboquadrina pachyderma (sin.) in the Arctic Ocean, Earth Planet. Sc. Lett., 146, 47-58, 1997.

Berger, A. and Loutre, M. F.: Insolation values for the climate of the last 10 million years, Quaternary Sci. Rev., 10, 297-317, https://doi.org/10.1016/0277-3791(91)90033-Q, 1991.

Biastoch, A., Böning, C. W., Getzlaff, J., Molines, J.-M., and Madec, G.: Causes of Interannual-Decadal Variability in the Meridional Overturning Circulation of the Midlatitude North Atlantic Ocean, J. Climate, 21, 6599-6615, https://doi.org/10.1175/2008JCLI2404.1, 2008.

Birks, H. J. B., Heiri, O., Seppä, H., and Bjune, A. E.: Strengths and weaknesses of quantitative climate reconstructions based on Late-Quaternary biological proxies, Open Ecol. J., 3, 68-110, https://doi.org/10.2174/1874213001003020068, 2010.

Bond, G. C. and Lotti, R.: Iceberg discharges into the North Atlantic on millennial time scales during the last glaciation, Science, 267, 1005-1010, 1995.

Bonne, J.-L., Steen-Larsen, H. C., Risi, C., Werner, M., Sodemann, H., Lacour, J.-L., Fettweis, X., Cesana, G., Delmotte, M., Cattani, O., Vallelonga, P., Kjær, H. A., Clerbaux, C., Sveinbjörnsdõttir, A. E., and Masson-Delmotte, V.: The summer 2012 Greenland heat wave: In situ and remote sensing observations of water vapor isotopic composition during an atmospheric river event, J. Geophys. Res.-Atmos., 120, 2970-2989, https://doi.org/10.1002/2014JD022602, 2015.

Carstens, J. and Wefer, G.: Recent distribution of planktonic foraminifera in the Nansen Basin, Arctic Ocean, Deep Sea Res. Pt. I, 39, S507-S524, https://doi.org/10.1016/S01980149(06)80018-X, 1992.

Carstens, J., Hebbeln, D., and Wefer, G.: Distribution of planktic foraminifera at the ice margin in the Arctic (Fram Strait), Mar. Micropaleontol., 29, 257-269, 1997.

Caulle, C., Penaud, A., Eynaud, F., Zaragosi, S., Roche, D. M., Michel, E., Boulay, S., and Richter, T.: Sea-surface hydrographical conditions off South Faeroes and within the North-Eastern North Atlantic through MIS 2: The response of dinocysts, J. Quaternary Sci., 28, 217-228, https://doi.org/10.1002/jqs.2601, 2013.

de Vernal, A. and Rochon, A.: Dinocysts as tracers of sea-surface conditions and sea-ice cover in polar and subpolar environments,
IOP Conference Series: Earth and Environmental Science, 14, https://doi.org/10.1088/1755-1315/14/1/012007, 2011.

de Vernal, A., Rosell-Melé, A., Kucera, M., Hillaire-Marcel, C., Eynaud, F., Weinelt, M., Dokken, T., and Kageyama, M.: Comparing proxies for the reconstruction of LGM sea-surface conditions in the northern North Atlantic. Quaternary Sci. Rev., 25, 2820 2834, 2006.

de Vernal, A., Hillaire-Marcel, C., Rochon, A., Fréchette, B., Henry, M., Solignac, S., and Bonnet, S.: Dinocyst-based reconstructions of sea ice cover concentration during the Holocene in the Arctic Ocean, the northern North Atlantic Ocean and its adjacent seas, Quaternary Sci. Rev., 79, 111-121, https://doi.org/10.1016/j.quascirev.2013.07.006, 2013a.

de Vernal, A., Rochon, A., Fréchette, B., Henry, M., Radi, T., and Solignac, S.: Reconstructing past sea ice cover of the Northern Hemisphere from dinocyst assemblages: Status of the approach, Quaternary Sci. Rev., 79, 122-134, 2013b.

Dokken, T. M. and Jansen, E.: Rapid changes in the mechanism of ocean convection during the last glacial period, Nature, 401, 458-461, 1999.

Dokken, T. M., Nisancioglu, K. H., Li, C., Battisti, D. S., and Kissel, C.: Dansgaard-Oeschger cycles: Interactions between ocean and sea ice intrinsic to the Nordic seas, Paleoceanography, 28, 491502, 2013.

Dufresne, J. L., Foujols, M. A., Denvil, S., Caubel, A., Marti, O., Aumont, O., Balkanski, Y., Bekki, S., Bellenger, H., Benshila, R., Bony, S., Bopp, L., Braconnot, P., Brockmann, P., Cadule, P., Cheruy, F., Codron, F., Cozic, A., Cugnet, D., de Noblet, N., Duvel, J. P., Ethé, C., Fairhead, L., Fichefet, T., Flavoni, S., Friedlingstein, P., Grandpeix, J. Y., Guez, L., Guilyardi, E., Hauglustaine, D., Hourdin, F., Idelkadi, A., Ghattas, J., Joussaume, S., Kageyama, M., Krinner, G., Labetoulle, S., Lahellec, A., Lefebvre, M. P., Lefevre, F., Levy, C., Li, Z. X., Lloyd, J., Lott, F., Madec, G., Mancip, M., Marchand, M., Masson, S., Meurdesoif, Y., Mignot, J., Musat, I., Parouty, S., Polcher, J., Rio, C., Schulz, M., Swingedouw, D., Szopa, S., Talandier, C., Terray, P., Viovy, N., and Vuichard, N.: Climate change projections using the IPSL-CM5 Earth System Model: from CMIP3 to CMIP5, Clim. Dynam., 40, 2123-2165, https://doi.org/10.1007/s00382012-1636-1, 2013.

Ehlers, J. and Gibbard, P. L.: The extent and chronology of Cenozoic Global Glaciation, Quaternary Int., 164-165, 6-20, 2007.

Elliot, M., Labeyrie, L., Dokken, T., and Manthe, S.: Coherent patterns of ice-rafted debris deposits in the Nordic regions during the last glacial (10-60 ka), Earth Planet. Sc. Lett., 194, 151-163, https://doi.org/10.1016/S0012-821X(01)00561-1, 2001.

Eynaud, F.: Dinoflagellate cysts counts of sediment core MD952009, PANGAEA, Unpublished dataset no. 94393, 2003a.

Eynaud, F.: Dinoflagellate cysts counts of sediment core MD952010, PANGAEA, https://doi.org/10.1594/PANGAEA.94394, 2003b.

Eynaud, F., Turon, J. L., Matthiessen, J., Kissel, C., Peypouquet, J. P., De Vernal, A., and Henry, M.: Norwegian sea-surface palaeoenvironments of marine oxygen-isotope stage 3: The paradoxical response of dinoflagellate cysts, J. Quarternary Sci., 17, 349-359, https://doi.org/10.1002/jqs.676, 2002.

Eynaud, F., De Abreu, L., Voelker, A., Schönfeld, J., Salgueiro, E., Turon, J. L., Penaud, A., Toucanne, S., Naughton, F., Sánchez Goñi, M. F., Malaizé, B., and Cacho, I.: Position of the Polar 
Front along the western Iberian margin during key cold episodes of the last $45 \mathrm{ka}$, Geochem. Geophy. Geosy., 10, Q07U05, https://doi.org/10.1029/2009GC002398, 2009.

Ezat, M. M., Rasmussen, T. L., and Groeneveld, J.: Persistent intermediate water warming during cold stadials in the southeastern Nordic seas during the past 65 k.y, Geology, 42, 663-666, https://doi.org/10.1130/G35579.1, 2014.

Gordon, C., Cooper, C., Senior, C. A., Banks, H., Gregory, J. M., Johns, T. C., Mitchell, J. F. B., and Wood, R. A.: The simulation of SST, sea ice extents and ocean heat transports in a version of the Hadley Centre coupled model without flux adjustments, Clim. Dynam., 16, 147-168, https://doi.org/10.1007/s003820050010, 2000.

Guiot, J. and de Vernal, A.: Transfer Functions: Methods for Quantitative Paleoceanography Based on Microfossils, in Developments in Marine Geology, vol. Volume 1, edited by: Hillaire, M. and De Vernal, A., 523-563, Elsevier, available at: http://www. sciencedirect.com/science/article/pii/S1572548007010184 (last access: 24 March 2014), 2007.

Guiot, J. and de Vernal, A.: Is spatial autocorrelation introducing biases in the apparent accuracy of paleoclimatic reconstructions?, Quaternary Sci. Rev., 30, 1965-1972, https://doi.org/10.1016/j.quascirev.2011.04.022, 2011a.

Guiot, J. and de Vernal, A.: QSR Correspondence "Is spatial autocorrelation introducing biases in the apparent accuracy of palaeoclimatic reconstructions?" Reply to Telford and Birks, Quaternary Sci. Rev., 30, 3214-3216, https://doi.org/10.1016/j.quascirev.2011.07.023, 2011 b.

Hátún, H., Sande, A. B., Drange, H., Hansen, B., and Valdimarsson, H.: Influence of the atlantic subpolar gyre on the thermohaline circulation, Science, 309, 1841-1844, https://doi.org/10.1126/science.1114777, 2005.

Head, M. J., Harland, R., and Matthiessen, J.: Cold marine indicators of the late Quaternary: the new dinoflagellate cyst genus Islandinium and related morphotypes, J. Quaternary Sci., 16, 621636, https://doi.org/10.1002/jqs.657, 2001.

Heikkilä, M., Pospelova, V., Hochheim, K. P., Kuzyk, Z. Z. A., Stern, G. A., Barber, D. G., and Macdonald, R. W.: Surface sediment dinoflagellate cysts from the Hudson Bay system and their relation to freshwater and nutrient cycling, Mar. Micropaleontol., 106, 79-109, https://doi.org/10.1016/j.marmicro.2013.12.002, 2014.

Heikkilä, M., Pospelova, V., Forest, A., Stern, G. A., Fortier, L. and Macdonald, R. W.: Dinoflagellate cyst production over an annual cycle in seasonally ice-covered Hudson Bay, Mar. Micropaleontol., 125, 1-24, https://doi.org/10.1016/j.marmicro.2016.02.005, 2016.

Hillaire-Marcel, C. and Bilodeau, G.: Instabilities in the Labrador Sea water mass structure during the last climatic cycle, Can. J. Earth Sci., 37, 795-809, 2000.

Hillaire-Marcel, C. and de Vernal, A.: Stable isotope clue to episodic sea ice formation in the glacial North Atlantic, Earth Planet. Sc. Lett., 268, 143-150, https://doi.org/10.1016/j.eps1.2008.01.012, 2008.

Hillaire-Marcel, C., De Vernal, A., Polyak, L., and Darby, D.: Size-dependent isotopic composition of planktic foraminifers from Chukchi Sea vs. NW Atlantic sediments - Implications for the Holocene paleoceanography of the western Arctic, Quaternary Sci. Rev., 23, 245-260, https://doi.org/10.1016/j.quascirev.2003.08.006, 2004.

Hoff, U., Rasmussen, T. L., Stein, R., Ezat, M. M., and Fahl, K.: Sea ice and millennial-scale climate variability in the Nordic seas $90 \mathrm{kyr}$ ago to present, Nat. Commun., 7, https://doi.org/10.1038/ncomms12247, 2016.

Jonkers, L., Moros, M., Prins, M. A., Dokken, T., Dahl, C. A., Dijkstra, N., Perner, K., and Brummer, G. J. A.: A reconstruction of sea surface warming in the northern North Atlantic during MIS 3 ice-rafting events, Quaternary Sci. Rev., 29, 1791-1800, https://doi.org/10.1016/j.quascirev.2010.03.014, 2010.

Jouzel, J., Delaygue, G., Landais, A., Masson-Delmotte, V., Risi, C., and Vimeux, F.: Water isotopes as tools to document oceanic sources of precipitation, Water Resour. Res., 49, 7469-7486, https://doi.org/10.1002/2013WR013508, 2013.

Jungclaus, J. H., Fischer, N., Haak, H., Lohmann, K., Marotzke, J., Matei, D., Mikolajewicz, U., Notz, D. and Von Storch, J. S.: Characteristics of the ocean simulations in the Max Planck Institute Ocean Model (MPIOM) the ocean component of the MPIEarth system model, J. Adv. Model. Earth Syst., 5, 422-446, https://doi.org/10.1002/jame.20023, 2013.

Kageyama, M., Paul, A., Roche, D. M., and Van Meerbeeck, C. J.: Modelling glacial climatic millennial-scale variability related to changes in the Atlantic meridional overturning circulation: a review, Quaternary Sci. Rev., 29, 2931-2956, https://doi.org/10.1016/j.quascirev.2010.05.029, 2010.

Kindler, P., Guillevic, M., Baumgartner, M., Schwander, J., Landais, A., and Leuenberger, M.: Temperature reconstruction from 10 to 120 kyr b2k from the NGRIP ice core, Clim. Past, 10, 887-902, https://doi.org/10.5194/cp-10-887-2014, 2014.

Kissel, C., Laj, C., Labeyrie, L., Dokken, T., Voelker, A., and Blamart, D.: Rapid climatic variations during marine isotopic stage 3: Magnetic analysis of sediments from Nordic Seas and North Atlantic, Earth Planet. Sc. Lett., 171, 489-502, https://doi.org/10.1016/S0012-821X(99)00162-4, 1999.

Kleinen, T., Osborn, T. J., and Briffa, K. R.: Sensitivity of climate response to variations in freshwater hosing location, Ocean Dynam., 59, 509-521, https://doi.org/10.1007/s10236-009-0189-2, 2009.

Kretschmer, K., Kucera, M., and Schulz, M.: Modeling the distribution and seasonality of Neogloboquadrina pachyderma in the North Atlantic Ocean during Heinrich Stadial 1, Paleoceanography, 31, 986-1010, 2016.

Laj, C., Kissel, C., and Beer, J.: High Resolution Global Paleointensity Stack Since 75 kyr (GLOPIS-75) Calibrated to Absolute Values, Timescales Paleomagn. Field, Geophysical Monograph Series, 145, 255-265, https://doi.org/10.1029/145GM19, 2004.

Li, C., Battisti, D. S., and Bitz, C. M.: Can North Atlantic sea ice anomalies account for DansgaardOeschger climate signals?, J. Climate, 23, 5457-5475, https://doi.org/10.1175/2010JCLI3409.1, 2010.

Locarnini, R. A., Mishonov, A. V., Antonov, J. I., Boyer, T. P., Garcia, H. E., Baranova, O. K., Zweng, M. M., and Johnson, D. R.: World Ocean Atlas 2009, Volume 1: Temperature, Ed. NOAA Atlas NESDIS 68, U.S. Government Printing Office, Washington, D.C., edited by: Levitus, S., 2010.

Manthé, S.: Variabilité de la circulation thermohaline glaciaire et interglaciaire en Atlantique Nord, tracée par les foraminifères planctoniques et la microfaune benthique, Bordeaux I., 1998. 
Marcott, S. A., Clark, P. U., Padman, L., Klinkhammer, G. P., Springer, S. R., Liu, Z., Otto-Bliesner, B. L., Carlson, A. E., Ungerer, A., and Padman, J.: Ice-shelf collapse from subsurface warming as a trigger for Heinrich events, P. Natl. Acad. Sci. USA, 108, 13415-13419, 2011.

Martinson, D. G., Pisias, N. G., Hays, J. D., Imbrie, J., Moore, T. C., and Shackleton, N. J.: Age dating and the orbital theory of the ice ages: development of a high-resolution 0 to 300,000-year chronostratigraphy, Quaternary Res., 27, 1-29, 1987.

Masson-Delmotte, V., Jouzel, J., Landais, A., Stievenard, M., Johnsen, S. J., White, J. W. C., Werner, M., Sveinbjornsdottir, A., and Fuhrer, K.: Atmospheric science: GRIP deuterium excess reveals rapid and orbital-scale changes in greenland moisture origin, Science, 309, 118-121, https://doi.org/10.1126/science.1108575, 2005.

Müller, J. and Stein, R.: High-resolution record of late glacial and deglacial sea ice changes in Fram Strait corroborates ice-ocean interactions during abrupt climate shifts, Earth Planet. Sc. Lett., 403, 446-455, 2014.

North Greenland Ice Core Project members: High-resolution record of Northern Hemisphere climate extending into the last interglacial period, Nature, 431, 147-151, https://doi.org/10.1038/nature02805, 2004.

Peck, V. L., Hall, I. R., Zahn, R., and Elderfield, H.: Millennialscale surface and subsurface paleothermometry from the northeast Atlantic, 55-8 ka BP, Paleoceanography, 23, PA3221, https://doi.org/10.1029/2008PA001631, 2008.

Radi, T., Bonnet, S., Cormier, M. A., de Vernal, A., Durantou, L., Faubert, É., Head, M. J., Henry, M., Pospelova, V., Rochon, A., and Van Nieuwenhove, N.: Operational taxonomy and (paleo)autecology of round, brown, spiny dinoflagellate cysts from the Quaternary of high northern latitudes, Mar. Micropaleontol., 98, 41-57, 2013.

Rasmussen, S. O., Andersen, K. K., Svensson, A. M., Steffensen, J. P., Vinther, B. M., Clausen, H. B., Siggaard-Andersen, M.L., Johnsen, S. J., Larsen, L. B., Dahl-Jensen, D., Bigler, M., Röthlisberger, R., Fischer, H., Goto-Azuma, K., Hansson, M. E., and Ruth, U.: A new Greenland ice core chronology for the last glacial termination, J. Geophys. Res., 111, D06102, https://doi.org/10.1029/2005JD006079, 2006.

Rasmussen, T. L. and Thomsen, E.: The role of the North Atlantic Drift in the millennial timescale glacial climate fluctuations, Palaeogeogr. Palaeocl., 210, 101-116, https://doi.org/10.1016/j.palaeo.2004.04.005, 2004.

Reimer, P. J., Bard, E., Bayliss, A., Beck, J. W., Blackwell, P. G., Bronk Ramsey, C., Buck, C. E., Cheng, H., Edwards, R. L., and Friedrich, M.: IntCal13 and Marine13 radiocarbon age calibration curves 0-50,000 years cal BP, Radiocarbon, 55, 1869-1887, 2013.

Rochon, A., de Vernal, A., Turon, J.-L., Matthiessen, J., and Head, M. J., (Eds.): Distribution of dinoflagellate cysts in surface sediments from the North Atlantic Ocean and adjacent basins and quantitative reconstruction of sea-surface parameters, AASP special pub., Dallas, Texas, 1999.

Sarjeant, W. A. S.: Fossil and living dinoflagellates, Academic Press Inc., London, UK, 1974.

Simstich, J., Sarnthein, M., and Erlenkeuser, H.: Paired $\delta 180$ signals of Neogloboquadrina pachyderma (s) and Turborotalita quinqueloba show thermal stratification structure in Nordic Seas, Mar. Micropaleontol., 48, 107-125, 2003.

Sterl, A., Bintanja, R., Brodeau, L., Gleeson, E., Koenigk, T., Schmith, T., Semmler, T., Severijns, C., Wyser, K., and Yang, S.: A look at the ocean in the EC-Earth climate model, Clim. Dynam., 39, 2631-2657, https://doi.org/10.1007/s00382-011-12392, 2012.

Svensson, A., Andersen, K. K., Bigler, M., Clausen, H. B., DahlJensen, D., Davies, S. M., Johnsen, S. J., Muscheler, R., Parrenin, F., Rasmussen, S. O., Röthlisberger, R., Seierstad, I., Steffensen, J. P., and Vinther, B. M.: A 60000 year Greenland stratigraphic ice core chronology, Clim. Past, 4, 47-57, https://doi.org/10.5194/cp-4-47-2008, 2008.

Swingedouw, D., Mignot, J., Braconnot, P., Mosquet, E., Kageyama, M., and Alkama, R.: Impact of freshwater release in the North Atlantic under different climate conditions in an OAGCM, J. Climate, 22, 6377-6403, 2009.

Swingedouw, D., Rodehacke, C. B., Behrens, E., Menary, M., Olsen, S. M., Gao, Y., Mikolajewicz, U., Mignot, J., and Biastoch, A.: Decadal fingerprints of freshwater discharge around Greenland in a multi-model ensemble, Clim. Dynam., 41, 695720, https://doi.org/10.1007/s00382-012-1479-9, 2013.

Telford, R. J.: Limitations of dinoflagellate cyst transfer functions, Quaternary Sci. Rev., 25, 1375-1382, https://doi.org/10.1016/j.quascirev.2006.02.012, 2006.

Telford, R. J. and Birks, H. J. B.: The secret assumption of transfer functions: problems with spatial autocorrelation in evaluating model performance, Quaternary Sci. Rev., 24, 2173-2179, https://doi.org/10.1016/j.quascirev.2005.05.001, 2005.

Telford, R. J. and Birks, H. J. B.: Evaluation of transfer functions in spatially structured environments, Quaternary Sci. Rev., 28, 1309-1316, https://doi.org/10.1016/j.quascirev.2008.12.020, 2009.

Telford, R. J. and Birks, H. J. B.: QSR Correspondence "Is spatial autocorrelation introducing biases in the apparent accuracy of palaeoclimatic reconstructions?", Quaternary Sci. Rev., 30, 3210-3213, doi:j.quascirev.2011.07.019, 2011.

Tolderlund, D. S. and Bé, A. W. H.: Seasonal Distribution of Planktonic Foraminifera in the Western North Atlantic, Micropaleontology, 17, 297-329, https://doi.org/10.2307/1485143, 1971.

Trachsel, M. and Telford, R. J.: Technical note: Estimating unbiased transfer-function performances in spatially structured environments, Clim. Past, 12, 1215-1223, https://doi.org/10.5194/cp12-1215-2016, 2016.

Van Meerbeeck, C. J., Renssen, H., and Roche, D. M.: How did Marine Isotope Stage 3 and Last Glacial Maximum climates differ? - Perspectives from equilibrium simulations, Clim. Past, 5, 33-51, https://doi.org/10.5194/cp-5-33-2009, 2009.

Volkmann, R. and Mensch, M.: Stable isotope composition $(\delta 18 \mathrm{O}$, $\delta 13 \mathrm{C}$ ) of living planktic foraminifers in the outer Laptev Sea and the Fram Strait, Mar. Micropaleontol., 42, 163-188, https://doi.org/10.1016/S0377-8398(01)00018-4, 2001.

Wary, M.: Rôle des conditions océaniques et des ice-shelves en périphérie des calottes européennes lors des évènements climatiques abrupts de la dernière période glaciaire, $\mathrm{PhD}$ thesis, Université de Bordeaux, available at: www.theses.fr/ 2015BORD0316/document, 2015.

Wary, M., Eynaud, F., Rossignol, L., Lapuyade, J., Gasparotto, M.-C., Londeix, L., Malaizé, B., Castéra, M.-H., and Char- 
lier, K.: Norwegian Sea warm pulses during DansgaardOeschger stadials: Zooming in on these anomalies over the 35$41 \mathrm{ka}$ cal BP interval and their impacts on proximal European ice-sheet dynamics, Quaternary Sci. Rev., 151, 255-272, https://doi.org/10.1016/j.quascirev.2016.09.011, 2016.

Wary, M., Eynaud, F., Zaragosi, S., Rossignol, L., Sabine, M., Castéra, M.-H., and Billy, I.: The Southern Norwegian Sea during the last $45 \mathrm{ka}$ : hydrographical reorganizations under changing ice-sheet dynamics, J. Quaternary Sci., https://doi.org/10.1002/jqs.2965, online first, 2017.
Wolff, E. W., Chappellaz, J., Blunier, T., Rasmussen, S. O., and Svensson, A.: Millennial-scale variability during the last glacial: The ice core record, Quaternary Sci. Rev., 29, 2828-2838, 2010.

Zumaque, J., Eynaud, F., Zaragosi, S., Marret, F., Matsuzaki, K. M., Kissel, C., Roche, D. M., Malaizé, B., Michel, E., Billy, I., Richter, T., and Palis, E.: An ocean-ice coupled response during the last glacial: a view from a marine isotopic stage 3 record south of the Faeroe Shetland Gateway, Clim. Past, 8, 1997-2017, https://doi.org/10.5194/cp-8-1997-2012, 2012. 